\title{
台湾における日本語文法の教材について \\ Textbooks of Japanese Grammar Available in Taiwan
}

\author{
王 敏東 \\ （台湾）銘傳大学 応用日本語学科
}

\section{要旨}

本稿は 2008 年末までの台湾で見られた日本語文法の教材を論ずるものである。具体的には台湾に ある 76 の図書館に所蔵されている日本語文法の教材を、時代別、編纂・内容別、元の出版地別、作 者別に検討し、そして、以下の結果を得た。

(1)台湾における日本語文法の教材は戦前までさかのぼることができる。戦後は、日本で作成され ているものの使用はかなり前からあったが、近年そのようなものに中国語訳や中国語注橎を付し、 新に台湾で出版されているようになっている。台湾人の手によって作られた日本語文法の教材の登 場は 1960 年代以降のことであるが、元中国大陸とホンコンという漢字文化圈で作られた教材は戦後 の台湾に進出している。

(2)学校文法における品詞から導入する教材が、最初に（戦前から）見られた編纂方式である。そ れに対して、特定のテーマを扱って一冊とした文法教材は戦後現れた。また、文型で文法を導入し た教材は 1970 年代より見られるようになってきている。なお、日本語能力試験の資格取得を目標と した教材は該当試験の出題基準が公布された 1990 年代初期以降のことである。

(3)学校文法における品詞から導入する教材は主に中国人によって作られている。日本語能力試験 に関する文法の教材の作成には日本人が大きな役割を果たしている。

キーワード:

品詞、文型、日本語能力試験 


\section{台湾における日本語文法の教材について}

\section{王 敏東 \\ （台湾）銘傳大学 応用日本語学科}

\section{1. はじめに}

教材は教育の内容をよく反映していると考えられる。同一範疇の教材を通時的に考察すれば、そ の範疇の軌跡または発展ぶりが分かる。

中国語母語話者が日本語を学ぶ際には、文法を頼りする傾向がある。また、成人が外国語を学習 する時、子供とは違い、“理解”を優先するともいわれている。それがゆえに、台湾に在住する多 くの日本語学習者は日本語文法の教材を大いに利用している。

本稿は 2008 年末までの台湾で見られた日本語文法の教材を論ずるものである。具体的には台湾に ある 76 の図書館に所蔵されている日本語文法の教材を、時代別、編纂 ・内容別、元の出版地別、作 者別に検討する。

\section{2. 本稿が取り扱う日本語文法の教材}

『新版日本語教育事典』（2005：895）では、教材は「効果的な授業を行うための道具であると同 時に、指導す心゙き内容を示すものである」と提示されており、辞書が「副教材」とされているうえ、 「生教材」についても触れられている1。が、『日本国語大辞典』（初版、1973 年）では、「教育の 目的を達成するために用いられる文化の素材」である教材は「教科書が中心である」と述べられて いる。

本稿が取り扱う日本語文法の教材は辞書を除き、教科書に限定する。

\section{3. 調查}

教材の調査期間は 2008 年 10 月下旬から 2008 年 11 月上旬までである。調査方法は、国家図書館 の「NBINet 聯合目録」」で「日語語法」、「日文文法」、「日語文法」、「日文語法」、「日本語 語法」、「日本語文法」、「日本口語文法」、「日文法」、「詞法」、「句法」をキーワードとし て検索し、その結果得られた関連書籍を「総論」、「特定の主題」、「文型」、「日本語能力試 験」に分け、年代順にリストアップするというものである（付録を参照）。

『新版日本語教育事典』（2005：898）。

「NBINet 聯合目録」は国家図書館の全館の書籍及び、図書館間相互協力に参加する 76 所の図 書館の所蔵する書誌情報である。 
現代日本語文法において大きな位置を占めている学校文法は戦前にすでに提示されている。この 学校文法では多くの場合、品詞を名詞・動詞・形容詞・形容動詞・副詞 · 連体詞 ・ 感動詞 ・ 接続 詞・助詞・助動詞の 10 種に分類する。

本稿の「総論」で分類している日本語文法の教材は、品詞ごとに導入され、日本語の全体につい て触れたものがほとんどである。

また、「特定の主題」に分類されているものは特定の品詞を取り扱ったものや、『日文長句分析 新聞日語語法』（1993、趙順文）のように特定のテーマを扱うものを含む。

外国人になるべく早く日本語を習得してもらう3「文型」については、現在こそこのように文型に

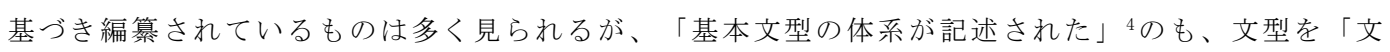
の構造に関する文型」「語の用法に関する文型」「表現の種々の場合における文型」という 3 種類 に分けたのも、1942 年に青年文化協会によって出版された『日本語練習用日本語基本文型』が最初 である5。なお、1963 年には国立国語研究所から『話しことばの文型：独話資料による研究』という 口語に限定したものが出版されている。これらの先行文献はいずれも文型により構成された教材の 先駆的な理論を構築したものである。

台湾で文型による文法の教材が数多く出版されるのは 1970 年代以降のことである。

ところで、1994 年の『日本語能力試験出題基準』（国際交流基金・日本国際教育協会）では「わ が国においては高等学校以下の教育課程は国が定める学習指導要領に準拠することになっているの で、学力試験はどの教科・科目においても学習指導要領を基準として出題することになっている。 ところが、日本語教育については現在まだこの学習指導要領に相当するものがない。」とされ、1 〜 4 級の文法（文型・文法事項）をリストアップし、「日本語能力試験においては級・類別に示さ れている認定基準を唯一の準拠として問題の作成に当たり、・少りり具体的な基準を示すことによっ て問題作成の参考に供する意図をしている」とのことである。また、この作業は日本では初めての 試みであることも提示されている ${ }^{6}$ 。その後の、2002 年に『日本語能力試験出題基準改定版』、文法

3 たとえば林（1960：19）ではこのような基本文型の第一開花期は日本の勢力が東南アジアに伸 びていった大東亜戦争（太平洋戦争 1941～1945）の進行時期であるとされている。

4 林 (1960) は当時「まだ国語の文型や基本文型の定説をもっていない」（該当書の「まえが き」）と指摘しながら、「起こした文型」「運び文型」「結び文型」「局部文型（相）」（該 当書の「第 2 部 文型の記述」）という4つの観点より文型を論じたうえ、「表現力を養う学 習」「読解を深めるための学習」「教師の目を肥やす」「参考ーホービーの英文型」（該当書 の「第 3 部 文型による学習」）の文型における教育上の意味にも触れている。林（1960： 18）は他にたとえば 1940 年の『国語教育』や、1941 年以降『コトバ』に散見されている論文 にも触れている。

5 関（1990：35）。ただし、筆者が確認した 1996 年の復刻版は「第一篇 表現の種々の場合に 於ける文型」 34 の文型、「第二篇 語の用法に関する文型」78 の文型に 3 つの付録、「文の構 造に関する文型」6つの部分、という構成となっていることが分かった。

6 この段落における内容のいずれも当書の「まえがき」による。 


\section{王 敏東：台湾における日本語文法の教材について}

の部分は $3 \cdot 4$ 級のリストに変更が見られる7。ちなみに、1990 年代より台湾で見られるようになっ た誤用関係の教材の大部分が、文法の誤用を多数取り入れている8。

数量の面からみれば、当然のようだが、戦前のものは少なく、戦後のものは漸次增えてきている。 台湾のこういう、日本語の文法教材の刊行状況は実は台湾の政治事情と梁くかかわっている。つま り、1940 年代は大東亜共栄圈構想における日本語教育のもとで日本語文法（文型）の教材が生まれ た。戦後国民党政府に返還された台湾は意識的に日本に関するものを排除しようとした ${ }^{9} 。 1960$ 年代 に入り、日本語の分かる人が減りつつあるのを感じ、大学で日本語学科を設立するようになった ${ }^{10} 。$ 日本語を専攻する場合の教材、とくに日本語の理屈・基盤を理解するのにどうしても必要な文法の 教材は 1970 年代より大いに発行された。1980 年代にさらに細分化され、専ら特定のテーマに関す る文法の教材が生まれ、1990 年代には日本語能力試験出題基準の公布に伴い、日本語能力試験に関 する教材も現れた。また、時代の進歩や、社会が豊かになるのに連れ、教材の多様性、作者の工夫 なども見られる。

\section{4. 分析}

この節では、教材を、時代別、編纂・内容別、元の出版地別、作者別に、それぞれ小節をたてて まとめる。

\section{1 時代別}

日本の最初の植民地であった台湾では、日本統治時期（1985～1945 年、以下「日治時期」）に、 植民地現地の台湾人を対象とした日本語教育が行なわれていた。当時使われていた教材にたとえば 『公学校用公民読本』などがある11。当時の教育の内容や教材についての研究は近年盛んにされてい る。そのような研究の中には、文法（動詞や文型）を中心に取り上げたものがある12。一方、日本で は『国語詳解日本口語文法』（1935、王玉泉） ${ }^{13}$ のようなものが出版されている。

詳細は 2002 年の改訂版の 233、237、253 ページを参照。

王・林 (2009)。

たとえば中国民国（台湾）行政院新聞局

（http://info.gio.gov.tw/ct. asp?xItem=18362\&ctNode=2527）により、「一九四六年, 迫不及待地廢止報紙的日文版、禁止使用日語與日文」（筆者訳：1946 年に一日も早く日本語 版の新聞を排除したい、日本語の使用も禁じられていた。）とある。

101963 年に文化、1966 年に淡江、1969 年に輔仁、1972 年に呉東という具合だった。 詳しいことは蔡（2003）を参照。

たとえば蔡（2003）、江（2006）、藤原（2006）など。

中国語で日本語の文法を解釈した書物である。発行所は「日本岡崎書店発行」で、発行日は

「中国民国二十四年三月二十日」、初版印刷の日付は「昭和十年三月八日」となっている。作 者の王氏が、日本に留学すること 14 年で著した日本語の文法教材である（当書の「序」によ る）。1 4 ページの「発音篇」と 485 ページの品詞文法から構成されている。筆者が見た台湾 大学図書館所蔵のものには、「人類学系李済之贈」の印判と「陳奇禄」のサインと思われるも のが見られる。 
現在台湾で見られる戦後日本語文法の教材の中で、最も早く出版されているものは 1950 年に刊行 されている丁卓の『實用日語文法』である ${ }^{14}$ 。この本は台湾大学図書館に所蔵されており、表紙は于 右任 ${ }^{15}$ 手による「琠用日語文法」という文字が、次のページは活字体で「雙關實用日語文法」とい う文字が印刷されている ${ }^{16}$ 。実はこの本は 1942 年に上海三通書店で初版が出され、台湾では前記 1950 年の版以外、1 953 年三版、1960 年五版がある。つまり、戦後しばらくの間、台湾ではもとも と中国大陸で製作された日本語文法の教材も使用されていたことが分かる ${ }^{17}$ 。この本は 18 ページの 「上篇読音」と 144 ページの「下篇 文法」（pp19１62）から構成されている。「緒言」に「本 書…簡繁適中、既可為初學之範本、更可供高級之參考」とあるように、初心者の範例にも、上級学 習者の参考にもなるように、という編集方針が見られる。文法の部分は品詞による分類で進められ ている。各節（品詞）はまず中国語で説明されており、そのうえ日本語例文に例文の中国語訳とい う、現在でも日本語文法の教材でよく採用されている形式となっている。

また、戦後台湾人の手によって編纂されている日本語文法の教材としては、蔡茂豊の 1962 年の 『最新標準 日本口語文法』 ${ }^{18}$ が先駆的なものである ${ }^{19}$ 。1973 年に氏は『現代日語文的詞法』と『現 代日語文的句法』という品詞論と構文論の教材 ${ }^{20}$ を出し、1987 年に両書をまとめて『現代日語文的 口語文法』という形で出版した。この中で『現代日語文的口語文法』は 2007 年に修訂 26 版となっ ている。蔡氏の文法教材は広く用いられており、その影響は広範囲に及ぶ。1970 年代に入ると文型 を中心に編纂されたものが見られ始める。そのような、文型を中心に編纂されたものとしては、現

14 丁氏は他に『中日會話集』（1936 年に上海求進書局、1940 年に上海三通書局、1948 年（22 版）台湾書店、1957 年（6 版）遠東、1963 年香港遠東、1966 年遠東など）も出している。ち なみに、台湾大学所蔵の 1948 年版の下冊に、作者丁卓のことが「上海語学専門学校教授」と 紹介されている。

15 于右任（1879～1964）は清の挙人で、『半哭半笑樓詩草』という当時の政治を風刺する著作を 発表し、清に指名手配され、1904 年に日本滞在中に同盟會に加入した。後に『神州日報』、

『民呼日報』、『民吁日報』などを創立し、国民革命を宣伝する。1913 年に革命の失敗によ り、日本に亡命し、半年ぐらい滞在した。中国に戻った後、陝西靖國軍總司令、國民政府定都 南京、任國民政府委員、監察院院長などを歴任した。書道家としても有名である。

16 本には「元台湾大学園芸学科教授の顧元亮の贈書」と明記されており、台湾大学図書館が新た に付けたカバーに「實用雙關日語文法」とある。ちなみに、顧氏は、1951 年に学科主任、 1962 年台湾大学教務長（『聯合報』（1962.8.11））、1964 年には教育の仕事に携わって 30 年の賞を教育部より授け（『聯合報』（1964.9.27））、1970 年に国科会講座教授（『聯合 報』（1970.3.14））、1972 年に考試委員（『聯合報』（1972.8.23））、1978 年に台湾大 学付属病院で亡くなった（『聯合報』(1978.5.18））。

17 この点については蔡（2003）も触れている。

18 蔡茂豊『現代日語文法的詞法』（1982（修訂五版）：前言）による。また、『最新標準 日本 口語文法』（1968（二版）：2）の「序」は 1962 年となっている。ただし、蔡茂豊『現代日 語文的口語文法』（1990 (六版））に提示されている1987 年「新版序」に「1953 年」となっ ている。

19 一方、他に楊楽亭の『最新日本語口語文法』（1962 年、五洲出版）という品詞で日本語を紹介 しているものもあるが、序や編集方針などが見当たらない。

20 ただし、蔡茂豊『現代日語文的口語文法』（1990（六版））に提示されている 1987 年「新版 序」に「1969 年」となっている。 


\section{王 敏東：台湾における日本語文法の教材について}

在台湾の各図書館に所蔵されている中では早稲田大学が刊行したものが最も古い。数年後、中国語 により注が付されているものもあった。さらに 1975 年には、『大学日語入門句型研究』（只素 珠） 21 という台湾人が作った文型の本が現れている。

また、「特定の主題」の文法教材が盛んに刊行されたのは 1980 年代以降のことである ${ }^{22}$ 。つまり、 日本語文法を総論的に説明したものでなく、より細分化した主題を中心に一冊の教材をなしたもの である。この年代における台湾の日本語学習者はもう日本語を概観的に学習するにとどまらず、日 本語のより細かく、詳細なことに関心を持つ段階に来ていることが裏付けられている。主題には特 定の品詞、特定の科目（教科）などが含まれる。各品詞を単行本に分けて紹介しているものとして は林錦川のものがあげられる ${ }^{23}$ 。また、『最新日語句型讀本』（1981、黄朝茂）、『日本語句型會 話』（1982、蔡茂豊）のような、日本語学科でよく開講されている科目用の教材を文型に沿って編 纂しているものもある。時期的にみれば、この時期はちょうど蔡（2003）が指摘した台湾における 日本語教育の転換期（1963～1980） と開放期（1980～1989）の境目にあたり、文法教材がこのよう に多様な形に進展したのもその時代に相応する特徴の1つであろう。

一方、専ら日本語能力試験を意識して編纂された文法の教材は 1990 年代以後現れるようになって きている。もちろんそれは日本語能力試験出題基準が公布された後のことである。この類の教材は 日本人が携わることが多く、もともと日本で出版され、後に台湾で中国語訳を添えるなど加工した ものも多い24。日本語能力試験が台湾で重要視されるにしたがって、関連する教材は大量に作成され ており、今後の発展ぶりも期待されよう。

また最近では、教師用（教授用）の ppt が添付されているものが現れた。それは実際の教室活動 に昔のスライドの代わりにパソコンを用いることが一般化していることと関係があると思われる。 王（2007：167）で、聴く能力の養成に特に配慮している観光日本語の教材について「近年テープで なく、CD を使用するようになっているのは時代的な特徴であろう」と述べているように、パソコン で簡単に利用できる教具の添付は「時代的特徵」の 1 つとも言えよう ${ }^{25}$ 。

21 当書の「編輯説明」によると、『大學日語入門 句型研究』は『大學日語入門』を自習または 予習するためのものだという。

221978 年の『日語動詞用法理論與例示』（英紹唐、衆文）もこの一種と見られるが、大槻文法や 橋本文法などを紹介したうえ、作者自分の意見も述べ、更に用例を提示されたもので、教材と いうより、研究書に近いものだと思われる。

23 たとえば、『日語形容詞・形容動詞語法之分析』（1985 年）、『日語接續詞・連體詞・感動詞 用法之分析』（1986 年）、『日語名詞語法之分析』（1987 年）、『日語助動詞語法之分析』 （1987 年）、『日語助詞用法之分析』（1987 年）、『日語副詞的句及修飾法』（1988 年）、 『形容動詞』（1991 年）などがある。いずれも文笙書局によって出版されている。

24 詳しいことは王（2007）や王・三隅（2008）などを参照。

25 ちなみに、日本語教材を多く出版している致良出版社によると、PC にダウンロードして閲覧す る電子ブックの元致良出版社出版の文法教材を a irtaBooks 華文電子により 2010 年に出版し ている。 


\section{2 編纂・ 内容}

編纂・内容別は前節で触れた品詞、特定の科目、文型や日本語能力試験に関するものの他、書名 に「大学」が含まれているものもある。最初のものは黄仲圖の 1957 年の『大學日文文法』である ${ }^{26} 。$ 作者の黄氏は 1947 年に台湾大学の総務主任をつとめ ${ }^{27} 、$ 他に『日文読本』（1958（初版）、1962 (修訂第三版））も出されている ${ }^{28}$ 。2 書とも「国立台湾大学福利社経銷」と明記されており、台湾 大学で使用されたかと思われる。ただし、戦後初めての日本語学科が設立されたのは 1963 年、台湾 大学に日本語学科が設立されたのは 1994 年であるから、氏の教材は第二外国語用のものだと分かる。 同じく大学の第二外国語に用いられた「大学日本語」に『新編大學日文法』（尹德壽、1975）もあ る ${ }^{29}$ 。それに対して、前節で述べた淡江大学の呉素珠の『大學日語入門 句型研究』（1975）や、東 点大学の蔡茂豊の文法教材は各々の大学日本語学科で用いられていた ${ }^{30}$ 。

また、「敬語」（早いものとして 1993 年に張康樂編譯の『日本敬語使用指南 基本句型與正確使 用法』）、専門用語（早いものとして 1982 年の黄國精の『餐飲業專用日語餐飲業常用語之句型分 類彙編』）、類義表現（早いものとして 1992 年の元中国大陸の『日本語文法的問題點解析 解決日 語助詞、助動詞、用言、體言、慣用型的諸問題』や、1993 年に鍾芳珍譯（中村豊美等原著）の『日 語「類似」表現系列 句型篇』があげられる）、更に 4 技能における「聴くこと」（『聽出好日文： 文法入門』（楊美玲、2006）、『聽出好日文：基礎句型 200』（楊美玲、2006）、『用聽的學日文句 型』（林心穎、2006））または「書くこと」（『寫出日語文法力』（楊美玲、2007））などを主題 としたものもある。

なお、とくに「口語」が書名に明示されているのは戦前の『国語詳解日本口語文法』（1935、王 玉泉）にさかのぼることができるが、戦後のものなら、『日本口語文法』（王述先、1956）31、

26 この本は 1961 年の「增訂再版」、1964 年の「增訂三版」、1967 年の「增訂四版」、1971 年の 「增訂五版」、そして 1974 年の「增訂六版」も見られる。

27 彭孟緝先生訪問紀録（1993）http://www. gamebase.com. tw/forum/conten . . o=78005293。 また、蔡（2003：78）によると、黄は師範学院（当時）と台湾大学で日本語を教えていたとい う。

28 黄の「読本」教材についてはたとえば蔡（2001）、王（2007：206）が触れている。

29 当書の「編輯大意」に「本書乃編者歷年在各大學所授日本語 (第二外國語) 之補充教材增補編著 而成」とある。また、氏の別の著書（『精編 NHK 日本語課程』）（http://www. douban. com/subject/3160787/）によると、作者は「尹德壽，早年服務新聞界，後留日多年，回臺灣 後歷任私立臺北醫學院、私立中國醫藥學院、私立中國文化大學、國立臺灣工業技術學院、國立 臺灣藝術專科學院等校教職, 對日語教育貢獻良多, 先後編著有《大學基礎日語》、《新編大學 日文法》、《日文法講義》、《密集基礎日語》、《旅日生活會話》、《觀光日語會話》、《新 日本語文選》等。」と紹介されており、氏が数多くの大学で日本語を教えたことが分かる。ち なみに、ここにあげた『新編大學日文法』は当時文法の教材にまだあまり見られない横書きと なっている。

30 淡江大学の日本語学科は 1966 年に、兝東大学の日本語学科は 1972 年に創立された。ちなみに、 蔡氏は呉東大学に移る前は、文化大学の日本語学科（1963 年に創立）にいた。

30 この本はカバーに「自修適用」と提示されている。 


\section{王敏東：台湾における日本語文法の教材について}

『最新日本口語文法』（楊楽亭、1961）、『現代日本口語文法』（丁顔梅、1973（初版））などが あげられ、いずれも品詞論による構成である。現在は、あえて「口語」と明示しないのが普通で、 逆に文語文法のものであれば、書名に明示されている ${ }^{32}$ 。

上述した特定の主題の文法教材に、特定の品詞に関するものはほとんど中国人作者となっている が、他の主題のものは日本人作者の（または日本人作者のものを中国人が翻訳などを加工した）も のが多い。

\section{3 元の出版地}

王（1997、1999、2007）、王・鄭（2002、2004）、鄭（2005）は、台湾における日本語教育の 現場で用いられている教材には、台湾で作られたものの他に、「日本のものに中国語訳や注勫など を入れて改めて台湾で出版されたもの」と「中国大陸やホンコンなど他の漢字文化圈で作られたも のを台湾の事情にあわせ、改めて出版したもの」もあると指摘している。とくに後者については 王・鄭（2002）が初めてその現象に気付き、後に王・鄭（2004）、鄭（2005）または王（2007）で より深く全面的な論考を行なった ${ }^{33}$ 。

今回の日本語文法の教材についての調查で、台湾で作られたもの以外にも、「日本のものに中国 語訳や注釈などを入れて改めて台湾で出版されたもの」と「中国大陸やホンコンなど他の漢字文化 圈で作られたものを台湾の事情にあわせ、改めて出版したもの」もあることが分かった。「日本の ものに中国語訳や注釈などを入れて改めて台湾で出版されたもの」については、早くから見られ、 現在は日本語能力試験に関するものが多い。

「中国大陸で作られたものを台湾の事情にあわせ、改めて出版したもの」も、早くから見られた が、1987 年の解厳以前の情勢下では、その教材の身元を明示されないものが多いかと思われる。ま た、中国大陸で出版されているものがそのまま台湾の図書館に所蔵されているものとしてはたとえ ば『日語語法疑難辨析』（1988、趙福泉）などがあげられる。ちなみに、この『日語語法疑難辨 析』は 1992 年に台湾の藤笛出版により繁体字版『日本語文法的問題点解析』として台湾で出版され ている。

また、ホンコンで出版されているものはとくに加工せずに、そのまま台湾で販売されている。そ れはホンコンではもともと台湾と同じく繁体字が使われているうえ、自由社会だからである。

\footnotetext{
32 本稿は現在台湾における大学の日本語学科が必ず必修科目として開講している現代日本語の口 語文法（王（2007）、李（2008）など）に適用される教材を論ずるものである。したがって、 文語文法の教材については触れない。

33 他にたとえば王・林（2009）や林（2009）は台湾で見られる誤用関係の教材にもそのようなも のがあることについて言及した。
} 


\section{4 作者}

王（2007：203）に「外国語教育に携わる場合、母語話者の立場からと目標言語話者の立場からと、 2 通りのアプローチが考えられ、中国人が日本語を教授する場合は後者に相当する。前者は、ネイ ティブであるから自然で適切な言語表現に基づく教材を作れるが、後者にも、自分の学習経験を生 かし、学習上困難な点などに配慮した教材を作れるというメリットが考えられる。」とあるが、文 法の教材でもそのようなことが観察できた。中国人向けの日本語文法の教材にも、日本人作者のも のと中国人作者のものとが存在する。この中では日本人作者によるものが早くから信頼されていた ようで、台湾ではたとえば早稲田大学、筑波大学、東京外国語大学、日本海外技術人員研修会など の団体や、寺村秀夫などの学者が携わっている文法の教材は広く使用されている。近年、とくに日 本語能力試験に関する教材は多種多様に出版されており、日本人作者がこの類の教材に大きな役割 を果たしている。しかし、前節（「元の出版地」）でも述べたように、日本人が編纂しており、も ともと日本で出版されて、本全体が日本語だけで構成されている日本語の教材は、中国語訳や中国 語注釈などがなければ、台湾で流布しにくいと思われる。とくに、文法の教材は規範の法則性を論 理的に説明するのが基本なので、日本語教育の対象である学習者の母語の介在がないと、内容の理 解が難しくなると思われる。

それに対して、日本語文法に対する総論や、各品詞についての説明のような教材は中国人独自で 完成されたものが多い。また、王（2001）では、台湾の日本語学科を持っている各大学で、学科な どグループ名義で作られている日本語の教材について論じた ${ }^{34}$ 。今回の調査で大葉大学応用日本語学 科も『大学日本語基礎 初級基礎文型で日常会話から応用会話まで』（2003）という基礎文型から出 発点とした教材を出版していることを確認した。

\section{5. 台湾の日本語教材における文法の教材の位置付け}

台湾で見られる日本語関係の教材については、これまで王（1997）がビジネス関係のもの、王 （1998）が観光日本語関係のもの、王（1999）が科学技術日本語関係のもの、王（2001）が大学が 作成した教材、王・鄭（2002、2004）、鄭（2005）が中国大陸・ホンコンとの教材の流通、王・林 （2009）が誤用関係の教材、についてそれぞれ論じてきている。また、前記のビジネス日本語、観 光日本語、科学技術日本語の教材について、王（2007）は改めて 2006 年の状況を調査した。それら の結果をまとめ、さらに本研究で取り扱う誤用関係の教材の流れを合わせて整理すると、表 I のよ うになる ${ }^{35}$ 。

\footnotetext{
34 そのような教材は文型を中心に編纂されているものがほとんでである。

35 表における左の部分は王・林（2009）の引用で、一番右の部分（『文法』）は筆者によりまと めたものである。
} 
王 敏東：台湾における日本語文法の教材について

表 I

\begin{tabular}{|c|c|c|c|c|c|c|}
\hline & ビジネス & 観光 & 科学技術 & 誤用関係 & 文法 \\
\hline \multirow{5}{*}{$\begin{array}{l}\text { 年 } \\
\text { 代 }\end{array}$} & $\begin{array}{l}\overrightarrow{0} \\
\text { 。 } \\
\circ \\
\text { 年 } \\
\text { 代 }\end{array}$ & $-{ }^{36}$ & - & - & - & $\begin{array}{l}\text { •もともと中国大 } \\
\text { 陸で製作された } \\
\text { のが使用されてい } \\
\text { た。 }\end{array}$ \\
\hline & $\begin{array}{l}\overrightarrow{0} \\
\text { \& } \\
\text { 年 } \\
\text { 年 } \\
\text { 代 }\end{array}$ & - & - & - & - & $\begin{array}{l}\text { ・台湾人の手によ } \\
\text { って編纂されたも } \\
\text { のが現れた。 }\end{array}$ \\
\hline & $\begin{array}{l}\overrightarrow{0} \\
\text { ○े } \\
\text { 年 } \\
\text { 代 }\end{array}$ & $\begin{array}{l}\text { •『商用 日 } \\
\text { 語』のような } \\
\text { ビジネス日本 } \\
\text { 語関係の専用 } \\
\text { 教材が見られ } \\
\text { るようになっ } \\
\text { た。 }\end{array}$ & $\begin{array}{l}\text { • 数が少な } \\
\text { い。 } \\
\text { •「観光日本 } \\
\text { 語」のみが } 1 \\
\text { 冊となってい } \\
\text { るものはなか } \\
\text { った。 } \\
\text { ・場面が細か } \\
\text { く限定された } \\
\text { ものが現れて } \\
\text { いる。 }\end{array}$ & - & - & $\begin{array}{l}\text { •文型を中心に編 } \text { 篹されたものが見 } \\
\text { れるようになっ } \\
\text { てきている。 }\end{array}$ \\
\hline & $\begin{array}{l}\overrightarrow{0} \\
\infty \\
\circ \\
\text { 年 } \\
\text { 代 }\end{array}$ & $\begin{array}{l}\text { •数が前より } \\
\text { 増えた。 } \\
\text { • } 1 \text { 冊の教材 } \\
\text { として内容 } \\
\text { が「商業 文 } \\
\text { 書」や「求 } \\
\text { 職」のように } \\
\text { 細かく分かれ } \\
\text { るようになっ } \\
\text { ている。 }\end{array}$ & $\begin{array}{l}\text { •観光に関す } \\
\text { るテーマのみ } \\
\text { で } 1 \text { 冊をなす } \\
\text { 教材が多くな } \\
\text { った。 } \\
\text { •取り扱われ } \\
\text { る場面は細か } \\
\text { くなた。 } \\
\text { ·教材の種類 } \\
\text { が多くなっ } \\
\text { た。 }\end{array}$ & $\begin{array}{l}\text { •1986 年には } \\
\text { じめて現れ } \\
\text { た。 }\end{array}$ & - & $\begin{array}{l}\text { •「特定の主題」 } \\
\text { (特定の品詞、特 } \\
\text { 定の科目(教科) } \\
\text { など) を扱ったも } \\
\text { のが盛んに刊行さ } \\
\text { れた。 }\end{array}$ \\
\hline & $\begin{array}{l}\overrightarrow{0} \\
8 \\
0 \\
\text { 年 } \\
\text { 代 }\end{array}$ & $\begin{array}{l}\text { ・1冊の本に } \\
\Gamma \text { 自己紹 } \\
\text { 介」、電 } \\
\text { 話」や「訪 } \\
\text { 問」など多数 } \\
\text { のテーマが入 } \\
\text { っいる総合 } \\
\text { 型の教材が大 } \\
\text { 量に出版され } \\
\text { た。 }\end{array}$ & $\begin{array}{l}\text { •依然として } \\
\text { 観光に関する } \\
\text { テーマのみで } \\
1 \text { 冊をなすも } \\
\text { のが多い。 } \\
\text { •従業員のた } \\
\text { め教材もあ } \\
\text { れば、観光客 } \\
\text { のためのもの } \\
\text { もる。 }\end{array}$ & $\begin{array}{l}\text { •1992 年に、 } \\
\text { 中国大陸で編 } \\
\text { 纂されたもの } \\
\text { を台湾で改め } \\
\text { て出版された } \\
\text { ものが現れ } \\
\text { た。 }\end{array}$ & $\begin{array}{l}\text { ・1990 年 } \\
\text { にはじめて } \\
\text { 現れた。 }\end{array}$ & $\begin{array}{l}\text { ・日本語能力試験 } \\
\text { を意識して編纂さ } \\
\text { れたものが現れる } \\
\text { ようになってを } \\
\text { た。 }\end{array}$ \\
\hline
\end{tabular}

36 その条件に当てはまるものがないのを「一」で示す。 


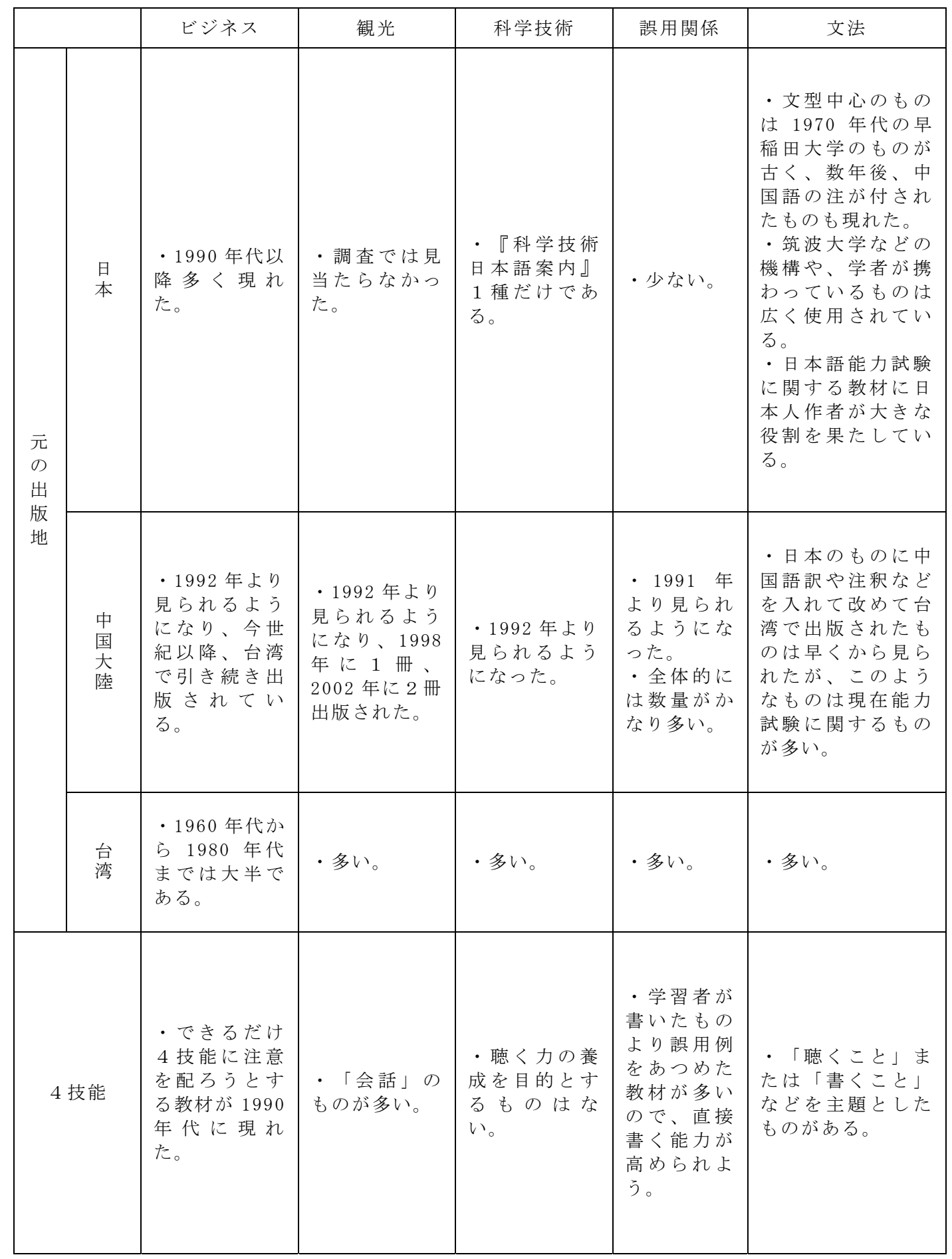


王 敏東：台湾における日本語文法の教材について

\begin{tabular}{|c|c|c|c|c|c|}
\hline & ビジネス & 観光 & 科学技術 & 誤用関係 & 文法 \\
\hline $\begin{array}{l}\text { 内容 } \\
\text { トピック }\end{array}$ & 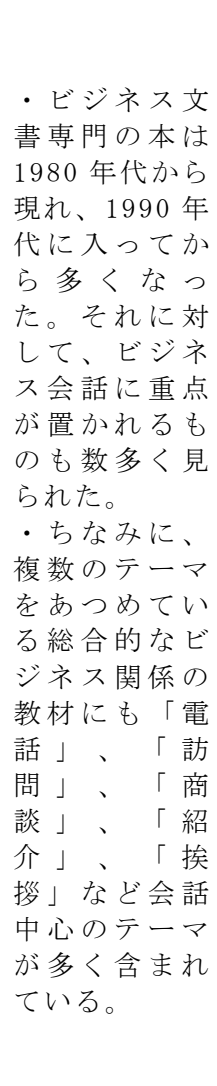 & 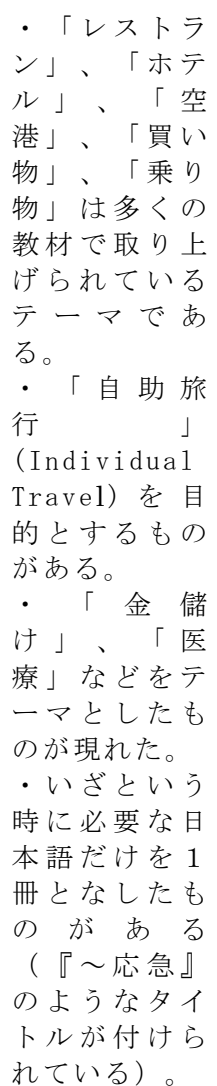 & $\begin{array}{l}\text { •「科技 (科 } \\
\text { 学技術)」旦 } \\
\text { 本語の教材が } \\
\text { 大半である。 } \\
\text { •さらに「軍 } \\
\text { 事篇」、「資 } \\
\text { 訊 (情報) } \\
\text { 篇」、「半導 } \\
\text { 体篇」という } \\
\text { サブタイトル } \\
\text { を付け、科学 } \\
\text { 技術の中の分 } \\
\text { 野をより細か } \\
\text { く分けたもの } \\
\text { もる。 }\end{array}$ & $\begin{array}{l}\text { ・すべての } \\
\text { 教材に語彙 } \\
\text { に関する誤 } \\
\text { 用が取り入 } \\
\text { れられてい } \\
\text { る。 } \\
\text { •表現の誤 } \\
\text { 、文法の } \\
\text { 誤り、表記 } \\
\text { の誤り、発 } \\
\text { 音の誤りの } \\
\text { 順で誤用関 } \\
\text { 係の教材に } \\
\text { 多く取り上 } \\
\text { げられてい } \\
\text { る。 }\end{array}$ & 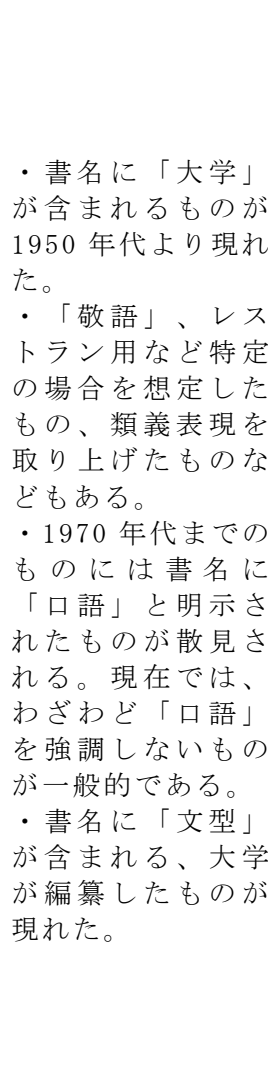 \\
\hline
\end{tabular}

表 I から教材の中での文法教材の位置について分かることをまとめると以下のようになる。

(1)台湾における日本語文法の教材は戦前までさかのぼることができ、そのようなものの中には、 中国大陸で作られたものを継承したものもある。戦後のかなり前、元日本で作成されているも のの使用はあったが、近年そのようなものに中国語訳や中国語注䣋を付し、新に台湾で出版さ れているようになっている。一方、台湾人が作った日本語文法の教材の出現は 1960 年代以降 のことである。他方、元中国大陸やホンコンのような漢字文化圈で作られた教材も戦後は台湾 に進出している。前者は簡体字を繁体字に、用語・例文などを台湾の事情にあわせて再編成し ているものがほとんどで、後者はそのまま台湾で販売されている。

(2)学校文法の品詞から導入する教材が最初に（戦前から）見られた編䉕方式である。それに対し て、特定のテーマを中心に一冊とした文法教材は戦後現れた。また、文型から文法を導入した 教材は 1970 年代より見られるようになってきている。このような文型文法は外国人を対象と する日本語教育が強く意識された産物である。なお、日本語能力試験の資格取得を目標とした 
教材は該当試験の出題基準が公布された後、1990 年代初期以降のことである。

(3)学校文法の品詞から導入する教材は、主に中国人によって作られている。一方日本語能力試験 に関する文法の教材の作成には日本人が大きな役割を果たしている。

このように日本語文法の教材を全面的に観察することにより、台湾における日本語文法教育の軌 跡・発展の過程を明らかにした。

\section{参考文献（年代順）}

王敏東・林益泓（2009）「誤用関倸の教材における位置付け一台湾の場合」『アジア・オセアニア 地域における多文化共生社会と日本語教育・日本研究 会議録 第一部』, pp303-309（The Eighth International Symposium on Japanese Language Education and Japanese Studies: Multiculturalism and Japanese Language Education/ Japanese Studies in Asia and 0ceania 2008, 香港)

林益泓（2009）『台湾における誤用関係の教材の一考察』銘傳大学応用日本語学科修士論文 王敏東（2007）『台湾における高等日本語教育及び関連の研究』致良出版社 藤原徹（2006）『臺灣教科用書國民讀本における一考察 文型 V ているを中心に』東吳大學日本語文 學系修士論文

江秀姿（2006）「『國民讀本參照國語科話方教材』の一考察一初版巻一・二を中心に一」『東吳日 語教育學報』29、pp1-28

日本語教育学会編（2005）『新版日本語教育事典』大修館書店 鄭恵如（2005）『台湾と中国大陸・香港の三ヶ所における日本語関係の書籍の交流一台湾を出発点

として一』銘傳大学応用日本語学科修士論文

王敏東・鄭惠如（2004）「漢語母語圈における日本語関係の書籍の交流一台湾 $\Leftrightarrow$ 中国大陸・香港を 中心に一」『日本語教育研究』46、pp $35-46$

蔡茂豊（2003）『台湾日本語教育の史的研究（上）（下）』大新書局

蔡錦雀（2003）「サ変動詞の未然形についての一考察一日本植民地時代の台湾公学校用国語読本を 中心に一」『南台應用日語學報』3、pp129-146

王敏東・鄭惠如（2002）「台湾における大学の日本語学科について一中国大陸、香港、マカオと連 携する道を探して一」『東亞日語教育國際研討會論文集（下）』中國日語教學研究會、pp729739、天津 


\section{王敏東：台湾における日本語文法の教材について}

国際交流基金・日本国際教育協会（2002）『日本語能力試験出題基準 改訂版』凡人社 蔡錦雀（2002）『日本植民地時代の台湾公学校用国語読本の研究』久留米大学博士論文 蔡錦雀（2002）「日本植民地時代の台湾公学校用国語読本の研究一第 5 期の『コクゴ』・『こく ご』・『初等科国語』を中心に（1）一」『蔡茂豐教授古稀記念論文集』、pp75-99 王敏東（2001）「台湾における大学作成の日本語教材について」『前田富祺先生退官記念論集 日

本語日本文学の研究』、pp187-195

蔡錦雀（2001）「日本植民地時代の台湾公学校用国語読本における語彙調查一以『臺灣教科用書國

民讀本』と『公學校用國民讀本』との比較を中心に一」『南台應用日語學報』創刊號、pp 201225

王敏東（1999）「台湾における科学技術日本語教育について」『日本語教育研究』38、pp99-112 王敏東（1998）「台湾における観光日本語関係の教材について」『日本語教育研究』36、pp93-104 王敏東（1997）「台湾におけるビジネス日本語関係の教材について」『日本語教育研究』34、 pp 128-141

国際交流基金・日本国際教育協会（1994）『日本語能力試験出題基準』凡人社 張健（1994）『于右任傳』雨墨文化事業 関正昭（1990）『外国人に教える日本語の文法』一光社 日本大辞典刊行会編（初版、1973 年）『日本国語大辞典』小学館 李漢雲（1973）『于右任的一生』台北市新聞記者公会 国立国語研究所（1963）『話しことばの文型：独話資料による研究』 林四郎（1960）『基本文型の研究』明治図書出版 青年文化協会（1942（1996 復刻））『日本語練習用日本語文型』至冬書房 内田吉徳（1941（1995ゆにま書房復刻））『コトバ』第三巻第二、三、四、六号 岡本千万太郎（1940）「基礎文型の種類」『国語教育』第二十五巻第三号、育英書院 岡本千万太郎（1940）「基礎日本語と基礎文型」『国語教育』第二十五巻第二号、育英書院 中国民国（台湾）行政院新聞局

http://info.gio.gov. tw/ct. asp?xItem=18362\& ct Node=2527

『教育部重編国語辞典』http://dict.revised.moe.edu.tw/ 


\section{付録（参考資料） 37}

表 i 各主題に関する教材（時代別） 38

\begin{tabular}{|c|c|c|c|c|}
\hline & 総論 & 特定の主題 & 文型 & 日本語能力試験 \\
\hline $\begin{array}{l}\overrightarrow{0} \\
\infty \\
0 \\
\text { 年 } \\
\text { 代 }\end{array}$ & $\begin{array}{l}\text { - 国語詳解日本口語文 } \\
\text { 法/王玉泉/1935/岡崎 } \\
\text { 屋書店 }\end{array}$ & & $\begin{array}{l}\text { - 日語動詞句型分析 } \\
(\text { (一) / 鄭正輝著、佐竹 } \\
\text { 博行協助/1930 (1) }\end{array}$ & \\
\hline 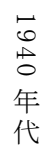 & & & $\begin{array}{l}\text { ・日本語練習用日本語 } \\
\text { 文型／青年文化 協会 } \\
\text { /1942（1996 復刻） } \\
\end{array}$ & \\
\hline $\begin{array}{l}\vec{e} \\
\text { 。 } \\
0 \\
\text { 年 } \\
\text { 代 }\end{array}$ & $\begin{array}{l}\text { • 實用雙關日語文法/丁 } \\
\text { 卓 / } 1950 （ 1953 \text { 、 } \\
\text { 1960) } \\
\text { - 大學日文文法/黄仲図 } \\
\text { (3) }\end{array}$ & & & \\
\hline $\begin{array}{l}\overrightarrow{6} \\
\mathscr{8} \\
0 \\
\text { 年 } \\
\text { 代 }\end{array}$ & $\begin{array}{l}\text { • 實用日語文法/丁卓 } \\
\text { /1960 } \\
\text { ·現代日本語文法/陳登 } \\
\text { 美/1969（1986） } \\
\end{array}$ & & & \\
\hline $\begin{array}{l}\overrightarrow{0} \\
\stackrel{0}{0} \\
\text { 年 } \\
\text { 代 }\end{array}$ & $\begin{array}{l}\text { ·現代日本口語文法/丁 } \\
\text { 顔 梅/1973（初版、 } \\
1991 \text { 九刷） } \\
\text { • 日語文法精粹 (日語華 } \\
\text { 譯 公式 )/王 瑾 潤 等 } \\
/ 1979 \quad(6)\end{array}$ & $\begin{array}{l}\text { - 日語動詞用法理論 } \\
\text { 與 例 示 / 英 紹 唐 } \\
/ 1978 / \text { 衆文 } \quad(1)\end{array}$ & $\begin{array}{l}\text { - 初級日語句型會話/ } \\
\text { 早稻田大學語學研究所 } \\
\text { 編/1971 (1979) } \\
\text { - 會話. 文法. 句型. 活 } \\
\text { 用日語入門/薛克旋 } \\
/ 1979\end{array}$ & \\
\hline $\begin{array}{l}\vec{b} \\
\infty \\
0 \\
\text { 年 } \\
\text { 代 }\end{array}$ & $\begin{array}{l}\text { - 現代日語語法概要/余 } \\
\text { 均灼/1980 } \\
\text { ·精簡易學日語文法/鄭 } \\
\text { 清祥/1989 }\end{array}$ & $\begin{array}{l}\text { ·最新日語句型讀本 } \\
\text { / 黄 朝 茂 / } 1981 \\
\text { (1997) } \\
\text { - 項目別日本語文法 } \\
\text { 問題集 初中級用 I } \\
\text { II III/山岡千弘、 } \\
\text { 山谷 陽子 編 著 } \\
\text { /1994、1999/大新 } \\
\text { (1989 建強) (7) }\end{array}$ & $\begin{array}{c}\text { - 現代日語句型研究 / } \\
\text { 左秀靈/1981（1984） } \\
\text { · 華 日百句型片語/ } \\
\text { 黃新源、徐運德/1989 } \\
(15)\end{array}$ & \\
\hline
\end{tabular}

37 本文に言及した教材は再掲しない。

38 紙幅の都合で、各欄の最も古いものと最新しいものだけを提示し、各欄の右下に該当範囲

(欄）に当る教材の数を明記する。表 ii 以下も同様。 
王敏東：台湾における日本語文法の教材について

\begin{tabular}{|c|c|c|c|c|}
\hline & 総論 & 特定の主題 & 文型 & 日本語能力試験 \\
\hline $\begin{array}{l}\text { 苟 } \\
\stackrel{2}{0} \\
\text { 年 } \\
\text { 代 }\end{array}$ & $\begin{array}{l}\text { • 簡明日本語語法/陳孟 } \\
\text { 臣/1991 } \\
\text { · 必用日語文法詳解/李 } \\
\text { 鴐英/1999 (32) }\end{array}$ & $\begin{array}{l}\text { • 文語口語對照日語 } \\
\text { 文法/王日和/1991 } \\
\text { •日本語文法論し可 } \\
\text { 能表現を中心にした } \\
\text { 助動詞「れる」「ら } \\
\text { れる」の研究/林綺 } \\
\text { 雲/1998 }\end{array}$ & $\begin{array}{l}\text { • 日語句型手册 / 張嫚 } \\
\text { /1990 } \\
\text { • 新编日语句型/马凤 } \\
\text { 鸣/1999/上 (27) }\end{array}$ & $\begin{array}{l}\text { ·新日本語能力 } \\
\text { 試驗對策考前總 } \\
\text { 複習文法重點整 } \\
\text { 理/渥見和重、高 } \\
\text { 橋 智加子、小柳 } \\
\text { 昇/1997 } \\
\text { ·日本語の重要 } \\
\text { 表現文型 日本語 } \\
\text { 能力試驗 } 1.2 \text { 合 } \\
\text { 格對策/池松孝 } \\
\text { 子、奧田順子 } \\
/ 1999 \quad(2) \\
\end{array}$ \\
\hline $\begin{array}{l}\stackrel{ }{ت} \\
\text { 世 } \\
\text { 紀 }\end{array}$ & $\begin{array}{l}\text { ·日語語法教程 / 吳 㑆 } \\
/ 2000 \\
\text { ·一本搞定日本語文法: } \\
\text { 基礎日本語文法 / 劉靜 } \\
\text { 慧、張淑惠 } / 2008 \\
\text { (38) }\end{array}$ & $\begin{array}{l}\text { ·日語語法之分析 } 1 \\
\text { 動詞、2 形容詞、 } 3 \\
\text { 名詞、4 助動詞、 } 5 \\
\text { 助詞、6 副詞、7 接 } \\
\text { 續詞. 連体詞. 感動 } \\
\text { 詞、 } 8 \text { 形容動 詞 } \\
/ 2001 \sim 2004 \text { 常用新聞日 } \\
\text { - NHK 最 } \\
\text { 語文法書/田中陽子 } \\
/ 2008 \text { (26) }\end{array}$ & $\begin{array}{l}\text { - 日本語重要句型用法 } \\
247 \text { /沈德高/2000 } \\
\text {-日語慣用句型全書 } \\
\text { /Chang Botao（常波 } \\
\text { 濤）/2008 (31) }\end{array}$ & $\begin{array}{l}\text { - 徹底強化日文 } \\
\text { 語法能力輕鬆通 } \\
\text { 過日語檢定測驗/ } \\
\text { 劉桂敏/2000 } \\
\text { • 日語能力測驗 } \\
4 \text { 級文法篇/陳 } \\
\text { 金順、王百祿、 } \\
\text { 張 耿明 } / 2008 \\
\text { (29) }\end{array}$ \\
\hline
\end{tabular}

表 ii 元の出版地

\begin{tabular}{|c|c|c|c|c|}
\hline & \multicolumn{2}{|c|}{ 品詞 } & \multicolumn{2}{|c|}{ 文型 } \\
\hline & 総論 & 特定の主題 & 文型 & 日本語能力試験 \\
\hline $\begin{array}{l}\text { 台 } \text { 湾 }\end{array}$ & $\begin{array}{l}\text { • 国語詳解日本口語 } \\
\text { 文法/王玉泉/1935/ } \\
\text { 岡崎屋書店/NTU } \\
\text { - 一本搞定日本語文 } \\
\text { 法: 基礎日本語文法 } \\
\text { /劉靜慧、張 淑惠 } \\
/ 2008\end{array}$ & $\begin{array}{l}\text { ·最新日語句型讀本/ } \\
\text { 黃朝茂/1981 (1997) } \\
\text { • 日語副詞速學/蘇阿 } \\
\text { 亮/2008 (31) }\end{array}$ & 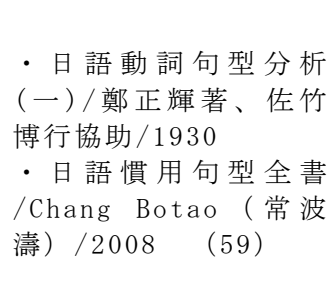 & $\begin{array}{l}\text { - 昂立教學系列 叢書 } \\
\text { 日本語能力考試 } 1-4 \\
\text { 級語法句型解析/閔 } \\
\text { 治平/2001 } \\
\text { ·日語能力測驗 } 4 \\
\text { 級 文法篇/陳金順、 } \\
\text { 王百 祿、張 耿 明 } \\
/ 2008\end{array}$ \\
\hline $\begin{array}{l}\text { 中 } \\
\text { 国 } \\
\text { 大 } \\
\text { 陸 }\end{array}$ & $\begin{array}{c}\text { ·實用雙關日語文法 } \\
\text { 丁 卓 / } 1950 \\
(1953 、 1960) \\
\text { ·基礎日本語文法/ } \\
\text { 趙福泉/2005（18） }\end{array}$ & $\begin{array}{l}\text { ·日語語法疑難辨析/ } \\
\text { 趙福泉/1988 } \\
\text { · 新日語語法 時、 } \\
\text { 體、志、語氣/王忻 } \\
/ 2001 \quad \text { (7) }\end{array}$ & $\begin{array}{l}\text { ·日語口語會話句型/ } \\
\text { 陳振汀/1985 } \\
\text { ·新编日语句型/马凤 } \\
\text { 鸣/1999/上海 } \\
\qquad(6)\end{array}$ & \\
\hline $\begin{array}{l}\text { 香 } \\
\text { 港 }\end{array}$ & $\begin{array}{c}\text { ·現代日語語法概要 } \\
\text { /余均灼/1980 } \\
\text { · } 21 \text { 世紀現代日語 } \\
\text { 語法/楊詘人、呉大 } \\
\text { 綱、龐黔林/2006 } \\
\text { (6) }\end{array}$ & $\begin{array}{l}\text { • 初級日語文法會話/ } \\
\text { 區潔鈴、石渡庸子編、 } \\
\text { 島田芳子主講、區潔 } \\
\text { 鈴、王同福注解/1988 } \\
\text { • 天天學日語語法/楊 } \\
\text { 羽/2004 (2) }\end{array}$ & & \\
\hline
\end{tabular}




\begin{tabular}{|c|c|c|c|c|}
\hline & \multicolumn{2}{|c|}{ 品詞 } & \multicolumn{2}{|c|}{ 文型 } \\
\hline & 総論 & 特定の主題 & 文型 & 日本語能力試験 \\
\hline $\begin{array}{l}\text { 日 } \\
\text { 本 }\end{array}$ & $\begin{array}{l}\text { ·国語詳解日本口語 } \\
\text { 文法/王玉泉/1935/ } \\
\text { 岡崎屋書店/NTU } \\
\text { 初級日語文法/左 } \\
\text { 秀靈譯/1988 (2) }\end{array}$ & $\begin{array}{l}\text { • 初級日本語文法練習 } \\
\text { 帳/東京外國語大學附 } \\
\text { 屬日本語學校編 著 } \\
/ 1991 \\
\text { • NHK 最常用新聞日語 } \\
\text { 文法 書 / 田中陽子 } \\
/ 2008 \quad \text { (15) }\end{array}$ & $\begin{array}{l}\text { • 初級日語句型會話/ } \\
\text { 早稻田大學語學研究所 } \\
\text { 編/1971 (1979) } \\
\text { ·日語常用句型 } 1000 \\
\text { I 〜 III/池畑裕介著、 } \\
\text { 黄清瑤、彭誼芝/2006 } \\
(2007) \quad(16)\end{array}$ & $\begin{array}{l}\text { ·新日本語能力試驗對策考前總複習文 } \\
\text { 法重點整理/渥見和 } \\
\text { 重、高橋智加子、小 } \\
\text { 柳昇/1997 } \\
\text {-日語能力測驗歷屆 } \\
\text { 試題與解析 } 2 \text { 級 文 } \\
\text { 法篇/獨立行政法人 } \\
\text { 國際交流基金、財團 } \\
\text { 法人日本國際教育資 } \\
\text { 源協會原著、趙順 } \\
/ 2008 \\
\text { (21) }\end{array}$ \\
\hline
\end{tabular}

